\title{
Studies on the Short-Term Effects of the Mobil Idoho Oil Spill on the Littoral Biota of Southeastern Nigeria
}

\author{
I. Ewa-Oboho* and O. Oladimej ${ }^{1}$ \\ Institute of Oceanography, University of Calabar, P.M.B. 1115, Calabar, Nigeria \\ ${ }^{\prime}$ Department of Food Technology, Awolowo University, Ile-Ife, Nigeria \\ *Corresponding author
}

\begin{abstract}
Quantitative surveys of the intertidal macro-fauna were conducted during September-October 1998 along transects established at various locations along the Nigeria coastline, following the rupture of a 24-inch pipeline at Idoho, off the Gulf of Guinea, southeastern Nigeria on 12 January 1998. Samples were taken within impacted areas and at control unpolluted sites approximately $5 \mathrm{~km}$ to the east of the Idoho off-shore platform. Spilled oil moved rapidly ashore and into river mouths, and estuaries and their mangals shortly after the spills. Biomass of macrofauna in the impacted areas tended to decrease with level of oiling, as the mean abundance decreased rapidly to about $50 \%$ of that found on the control unpolluted sites. Edible gastropod, mainly species of Tympanotomus fuscatus, and the brachyuran decapod, Uca tangeri, typically consumed by coastal inhabitants, had reduction in mean densities (up to 62\%) in the oiled Bonny, Brass, Lagos and Forcados than in the non-oiled areas of Imo, Andoni and Cross River, showing partial recovery of the environment from the debacle after 9 months. The ecological implications of these findings are discussed.
\end{abstract}

\section{Introduction}

A 24-inch oil pipeline ruptured at Mobil-Idoho platform on the inner shelf of the Atlantic coast of southeastern Nigeria on 12 January 1998 releasing over 40,000 bbls (approxi-mately 6,000 tones) of Qua Iboe light crude oil into the marine environment over the next three days. More than 700 $\mathrm{km}$ of the Nigerian coastline including estuaries were impacted. Within the impacted zone were a number of macro-benthic communities, the dominant species of which included the edible gastropod, Tympanotomus fuscatus, the Ocypodid brachyuran, Uca tangeri and Ocypode cursor, and several species of bivalves and polychaetes. Some of the estuaries that were oiled are known to be subject to pollution from a number of sources including hydrocarbon, sewage, metal, etc., showing that the spill was not in a pristine environment. It was, therefore, essential to include as many factors as possible in the sampling programme to look at the spill effects.

In September 1998, 9 months after the oil came ashore, a rapid assessment survey was conducted at nearly all the estuarine/river mouths along the Nigerian coastline both within the oil impacted estuaries and at the clean control site, $5 \mathrm{~km}$ east of the ruptured point. This included measurement of physical and chemical parameters of sea water, and presence and absence of typical macrobiota, together with estimates of overall abundance at each site. Analysis of biota and physical characteristics demon-strated that a full range of Nigeria coastline habitat was present within the impacted area (Ewa-Oboho, 1998). As separation and classification of intertidal habitats were possible on the basis of macrobiota alone, this survey demonstrated that earlier predictions of massive species elimination were unfounded, and the result provided the basis for selection of permanent sites for longer-term studies published elsewhere (Ewa-Oboho, in press). Nine months after the spill, a number of species (diversity) and individual species abundance were still lower at oiled areas in comparison with similar habitat clean control site. While normal diversity appeared to be the case at low tide levels of most impacted estuaries, the mid and the high tidal diversities ranged from 20 to $45 \%$ of the diversity on control sites.

One major problem plaguing marine biologists is the identification of short-term impacts of spill petroleum hydrocarbons on off-shore marine environments due to the open, complex and very dynamic nature of the system (Boesch \& Rosenberg, 1981). This is because effects are usually subtle, requires much funding and the relevant experimentation great. In most cases, natural variability in space and time often overshadow impact effects or confounds the resolution 
of such effects (Mcintyre \& Pearce, 1980; Lewis 1982; Clark, 1982; Koons \& Gould, 1998; EwaOboho, 1988, 1994).

Limits of detection which are dependent upon the sampling design could plague identification also. Insensitive methods using design with poor powers are capable of detecting only the gross effect, and have little to contribute to determination of potential subtle effects (Boesch et al.,1986). Effects of other human activities may complicate assessment, as practical difficulties are encountered in the comparisons of various uses and assignments of cause of observed alterations among users. Besides, ecosystem compounds are complexly interralated and variation or alteration in one biotic components may have subtle repercussions in another, thus, contributing to the lingering uncertainty about adequate understanding of the effects of off-shore oiling.

Recovery gaps do exist about the process and rates of recovery of living resources and ecosystem after oil perturbation. Thus, time required for a system to recover, however defined, can be use as a measure of significance of the spill effect (Oviatt et al. 1992, 1994). As Sell et al. (1995) has demonstrated, the natural recovery of some tropical oiled intertidal habitats elsewhere may take at least 5 years while McGlade \& Price (1993) predicted 6-10 years. This paper summarizes results from quantitative surveys of macrobiata 9 months after oiling using standard techniques, designed to be capable of detecting the degree of environmental change which could be considered unacceptable.

\section{Sampling methods and locations}

\section{Materials and methods}

The sampling area stretched from a control location, $5 \mathrm{~km}$ east of the pipe break point in Cross river estuary (40 $32^{\prime}: 06^{\prime \prime} \mathrm{N}$ and $08^{\circ} 04^{\prime \prime}: 46^{\prime \prime} \mathrm{E}$ ) to Takwa bay (Lagos) $06^{\circ} 47^{\prime \prime} \mathrm{N}$ and $03^{\circ} 32^{\prime}: 51^{\prime \prime}$ E) (Fig. 1) approx. $700 \mathrm{~km}$ east of the spill spot. Five heavily oiled estuaries (R. Bonny, R. Brass, R. Forcados, R. Escravos and Lagos Lagon), together with four unoilded ones (R. Imo, Cross river, Qua river and R. Nicholas) (Fig. 1) were chosen for sampling. Also, Bonny, Sangana, New Calabar, Andoni and Nun rivers were sampled at random. In total 104 stations were sampled during the period 15 September-30 October 1998. Two creeks were sampled per river, two transects per creek and two stations per transect.

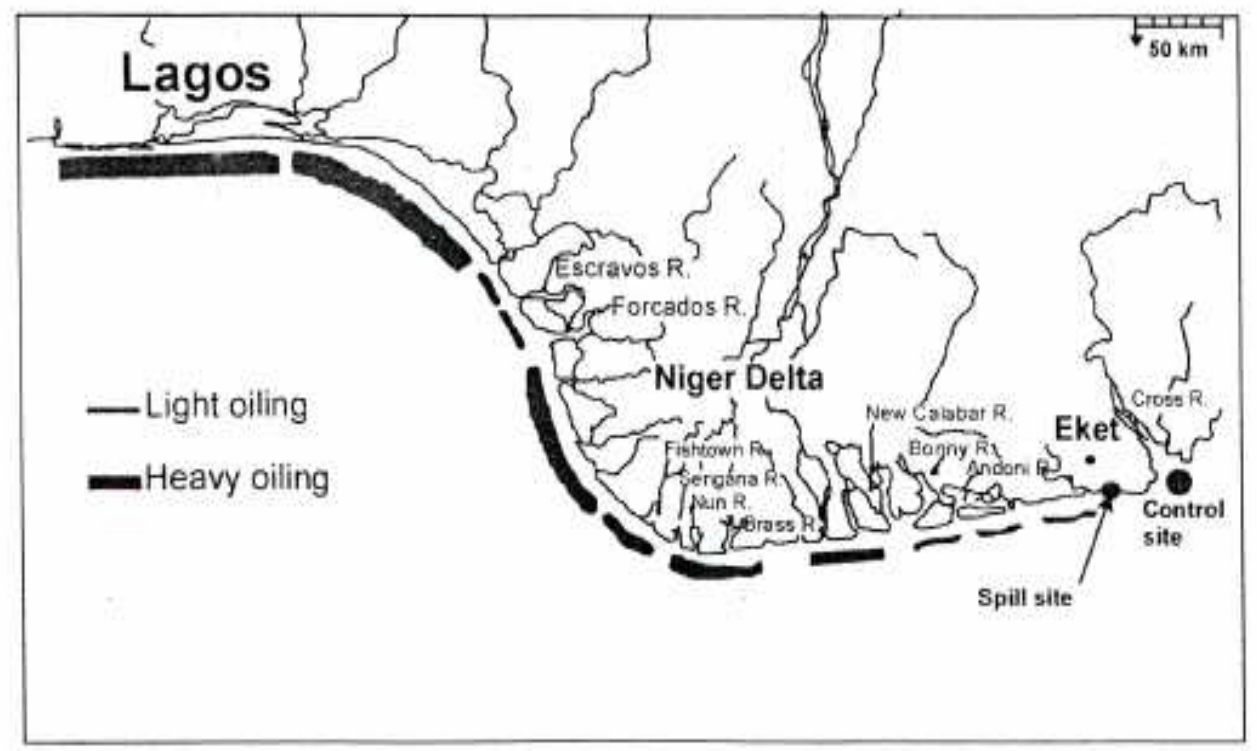


Fig. 1. Shoreline oiling map from aerial video survey on 16, 17 and 28 January 1998 showing oiled areas along the Nigeria coastline

Sampling stations were positioned at two shore levels, upper eulittoral (UE) and middle eulittoral (ME) together with the subtidal fringe, when tides allowed, based on biotic zonaton (Jones, 1986). Epibenthos was sampled by taking five random $1 \mathrm{~cm}^{2}$ quadrats, and macrobiota recorded as percentage cover, or counted where appropriate. On soft bottom sites, a $0.25 \mathrm{~m}^{2}$ area was initially sifted by hand for microbiota and then all surface material scrapped (to $10 \mathrm{~cm}$ depth) and sieved. This allowed discrimination between live and dead mollusks. Infaunal benthos were sampled by tripricate $0.1-\mathrm{m}^{2}$ cores to a depth of $15 \mathrm{~cm}$. These were sieved using a $1-\mathrm{mm}$ mesh and fauna preserved in formalin for identification and counting under a stereomicroscope. Only heads were counted for broken polychaetes. Average station values of abundance and biomass were used for analysis.

Records from key species sheets were entered into a computer and subjected to the following methods of analysis to determine similarities between stations and shore levels based on species lists. These included:

i) Principal component analysis based on species presence and absence data.

ii) Covariance matrix using species presence at more than two stations, and

iii) Hierarchical agglomeration (cluster analysis) using Tanimoto and Kulazynki indices (Jones \& Richmond, 1993; Prena, 1996). Both principal component analysis and cluster analysis separated sand, mud and mangrove habitats clearly based on biota alone, confirmed by comparison with physical data collected from each site and provide a habitat classification for all sites for future longer-term observation (Ews-Oboho, 1998; Jones \& Richmond, 1993; Jones et al., 1996).

\section{Sediments}

Sediment grade analyses and organic carbon measurements were made on replicate samples collected from undisturbed sediment at each station. Sediment samples were obtained with a corer down to a depth of $10 \mathrm{~cm}$. Their salt content was removed in the laboratory (McManus \& Buller, 1975). Sediment grade analyses were carried out by dry-sieving and pipette analysis (Buchanan \& Kain, 1977), while the organic content of sediment was determined by the wet dichromate oxidation method (Morgans, 1956).

\section{Environmental setting - physical conditions}

\section{Results}

Based on numerical analysis, sediment distribution in the creeks of the estuaries were predominantly silt-clay (72-95\% silt clay) (Table 1). In the sublittoral areas along river channels and at river mouths, sediments were mostly sand, due perhaps to the high water velocity in these environments. The mean values of silt-clay per river (creek) was 90\%. Sediment in Lagos, Forcados, Brass, Qua Iboe, Imo and Cross River had high organic carbon content with corresponding low species diversity (Table $1, \mathrm{R}=0.75$ ). Though sediment could represent an important source of food for sediment-dwelling benthos, the low number of species found in Lagos, Forcados, Brass and Bonny, despite high percentage organic carbon, could be attributed to the presence of toxic hydrocarbons bound to the clay-silt sediment. Generally, high values of organic carbon were found in the oiled areas as compared to that in the unoiled control estuaries $(P<0.05$ F-test One-Way Anova).

TABLE 1

Sediment distribution and percentage organic carbon content in oiled and control estuaries with corresponding number of species 


\begin{tabular}{|c|c|c|c|c|c|}
\hline Lagos & & 95 & 5 & $6.5 \pm 3.0$ & 6 \\
\hline Escravos & & 87.4 & 12.6 & $8 \pm 0.2$ & 8 \\
\hline Forcados & & 91.4 & 12.6 & $5.9 \pm 03$ & 6 \\
\hline Bonny & & 72.5 & 27.9 & $4.6 \pm 0.2$ & 10 \\
\hline Brass & & 86.1 & 22.1 & $5.3 \pm 0.2$ & 5 \\
\hline Andomi & & 85.8 & 13.9 & $1.8 \pm 0.2$ & 20 \\
\hline Imo River & & 89.2 & 10.8 & $1.8 \pm 0.2$ & 18 \\
\hline Cross River & 95.3 & 4.7 & $2.6 \pm 0.2 \quad 18$ & & \\
\hline
\end{tabular}

\section{Benthic survey}

To reduce the risk of considerable error in statistical computation, benthic counts in this study were transformed to normalized data and increase precision, using the log-transformation. This eliminated the dependence of variance on means. The Arcsine transformation which is especially appropriate for percentages and proportions was also applied where necessary. A total of 3,264 organisms, comprising species of macro-zoobenthic forms, were collected during the survey. Polychaetes and crustaceans dominated by species and number $(31.2 \%, 55.6 \%)$ and $(20.8 \%$, $28.9 \%)$, respectively. They were followed by molluscs (16.9\%). The mean biomass contributed by each of the three major taxa is shown in Table 2. There was no correspondence between the distribution of biomass and the position of clusters. This is reflected in the high variance of the mean biomass within the clusters. Generally, however, biomass decreased with level of oiling (Table 2), the highest biomass occurring in clusters of slight or no oiling. Thus, the biomass of the macrofauna in the oiled area in the Niger delta, in general, appears to be dominated by molluscs.

TABLE 2

Species and biomass distribution of major taxa in relation to level of oiling in the study area, 1998

\begin{tabular}{|c|c|c|c|c|c|c|c|c|c|}
\hline \multirow[t]{2}{*}{ Cluster } & \multicolumn{3}{|c|}{ Polychaetes } & \multicolumn{3}{|c|}{ Mollusks } & \multicolumn{3}{|c|}{ Crustaceans } \\
\hline & Species & Ind. & Biomass & Species & Ind. & Biomass & Species & Ind. & Biomass \\
\hline $\begin{array}{l}\text { Heavily } \\
\text { oiled }\end{array}$ & 15.8 & 432 & 1.0 & 12.7 & 265 & 1.6 & 17.2 & 182 & 0.9 \\
\hline $\begin{array}{l}\text { Lightly } \\
\text { oiled }\end{array}$ & 18.5 & 586 & 1.7 & 15.1 & 400 & 3.5 & 20.1 & 601 & 2.2 \\
\hline No oil & 17.2 & 448 & 2.4 & 18.3 & 368 & 4.8 & 12.3 & 321 & 2.3 \\
\hline Control & 18. & & 526 & 20 & 652 & 3.8 & 48.9 & 626 & 2.0 \\
\hline
\end{tabular}

The stations (rivers) were grouped on the basis of their degree of oiling after the spill, namely heavily oiled, lightly oiled, no oil and control. Table 3 shows the mean abundance of the five most abundant macro-zoobenthos in each cluster. Among the three main taxa polychaetes, molluscs and crustaceans), polychaetes had the highest species number per station while crustaceans had the lowest in all clusters (Table 3). In terms of abundance, all clusters, excecpt the control, were numerically dominated by polychaetes (Table 3). The species Capiteilla capitata and Polydora dominated the heavily oiled cluster while the species Scolopus fragalis, Nereis and Megalone papillicomis were the dominant polychaetes in the no oil cluster (Imo river), Noticeable, however, were high densities of molluscs in the control cluster (Cross river). 
Mean abundance of major taxa in relation to level of oiling

\begin{tabular}{|c|c|c|c|c|c|c|}
\hline Cluster & Species & $\begin{array}{l}\text { Mean } \\
\text { abundance } \\
\text { (Ind. } \mathrm{m}^{-2} \text { ) }\end{array}$ & $\begin{array}{l}\text { Numerical } \\
\text { dominance } \\
\%\end{array}$ & Presence (\%) & $\begin{array}{l}\text { Degree of } \\
\text { association } \\
\text { regarding } \\
\text { individual (\%) }\end{array}$ & $\begin{array}{l}\text { Degree of } \\
\text { association } \\
\text { concerning } \\
\text { stations (\%) }\end{array}$ \\
\hline \multirow{5}{*}{$\begin{array}{l}\text { Heavily Oiled } \\
\text { (Escravos, Lagos) }\end{array}$} & Nereis sp. & 86 & 9 & 30 & 92 & 74 \\
\hline & Capitella capitata & 98 & 10 & 86 & 30 & 88 \\
\hline & Polydora & 80 & 8 & 86 & 65 & 50 \\
\hline & Aphrodite aculeate & 62 & 6 & 94 & 25 & 21 \\
\hline & Uca tangeri & 126 & 3 & 90 & 36 & 68 \\
\hline $\begin{array}{l}\text { Light oiled } \\
\text { (R. Brass) }\end{array}$ & Syllis protifera & 68 & 7 & 100 & 28 & 81 \\
\hline \multirow[t]{4}{*}{ mud, sandy } & Nepthys sp. & 79 & 7 & 82 & 45 & 25 \\
\hline & Mya arenaria & 85 & 9 & 84 & 62 & 30 \\
\hline & Balanus balaniodes & 112 & 13 & 96 & 25 & 80 \\
\hline & Uca tangeri & 60 & 11 & 64 & 78 & 72 \\
\hline \multirow{6}{*}{$\begin{array}{l}\text { No oil (Imo R.) } \\
\text { sandy, mud }\end{array}$} & Tellina fibula & 90 & 5 & 22 & 16 & 65 \\
\hline & Tympanotomus & & & & & \\
\hline & fuscata & 510 & 3 & 78 & 38 & 30 \\
\hline & Mya arenaria & 102 & 6 & 88 & 7 & 45 \\
\hline & Balanus balaniodes & 46 & 3 & 72 & 16 & 60 \\
\hline & Uca tangeri & 128 & 9 & 94 & 25 & 12 \\
\hline \multirow{5}{*}{$\begin{array}{l}\text { Control } \\
\text { (Cross River) }\end{array}$} & Glycera & 52 & 8 & 100 & 16 & 65 \\
\hline & Mya arenaria & 56 & 8 & 100 & 38 & 30 \\
\hline & Thais califera & 40 & 6 & 89 & 7 & 48 \\
\hline & Uca tangeri & 120 & 15 & 100 & 16 & 60 \\
\hline & $\begin{array}{l}\text { Tympanotomus } \\
\text { fuscata }\end{array}$ & 174 & 18 & 72 & 55 & 12 \\
\hline
\end{tabular}

Fig. 2 shows species abundances in relation to percentage organic carbon for the impacted and the un-impacted estuaries. Mean abundance of species decreased rapidly to about $50 \%$ of that found on the control and the unimpacted areas with polychaetes as the dominant taxa. The surge in sediment organic carbon as found in Qua river could be ascribed to the chronic discharge of hydrocarbons in Ibeno oil terminal operational area. The mean spatial species abundance for two edible macro-benthos, Tympanotomus fuscata, and the fiddler crab, Uca tangeri, are shown in Fig. 3. After 9 months of oiling, mean population densities were $58-62 \%$ in the oiled areas of Lagos, Brass and Bonny than in the no oil areas of Imo river, Andomi and the controls areas of Cross river, where densities of 280 and 250 individuals $\mathrm{m}^{-2}$ were recorded for periwinkles and crabs, respectively. This showed that recovery was yet to be achieved at the mid and high tidal marks. 


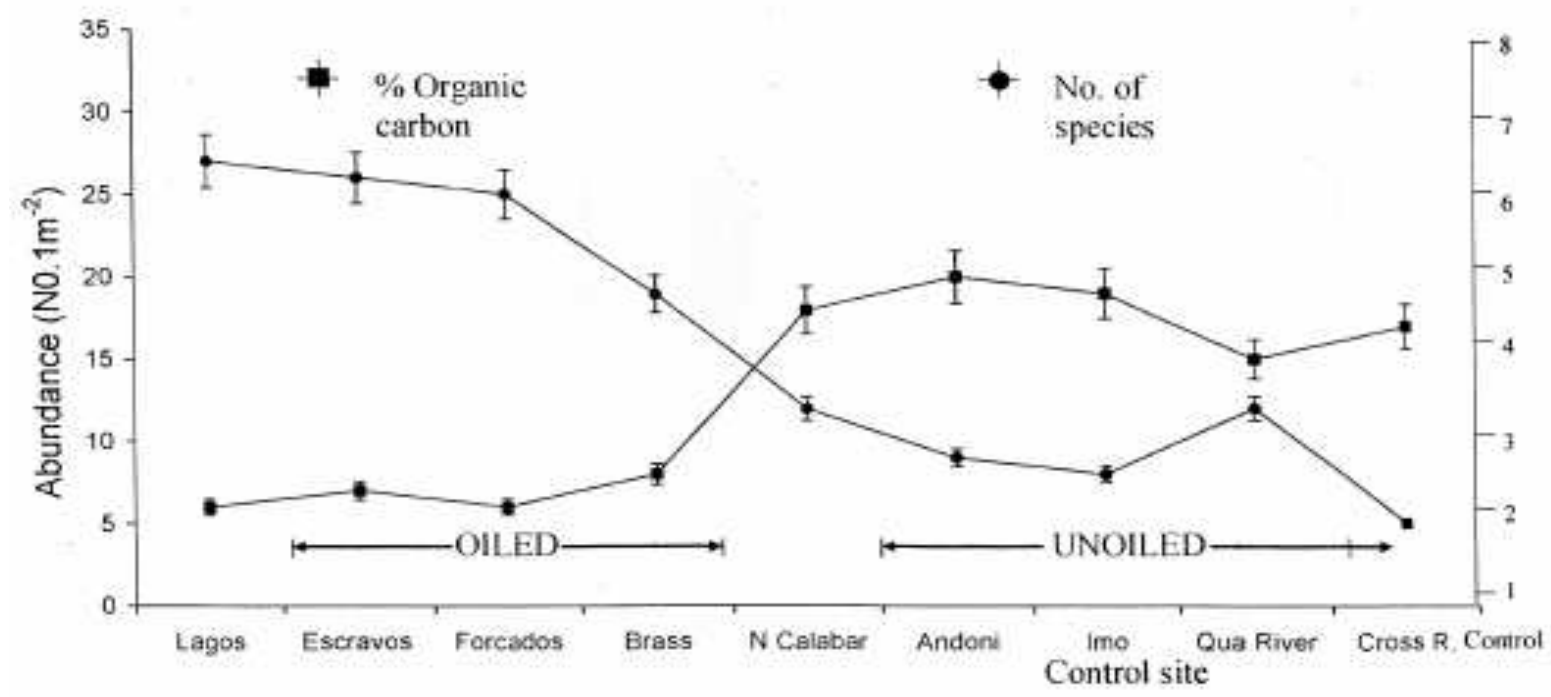

Fig. 2. Spatial variation in percentage organic carbon of sediment with corresponding species diversity in the oiled and non-oiled areas

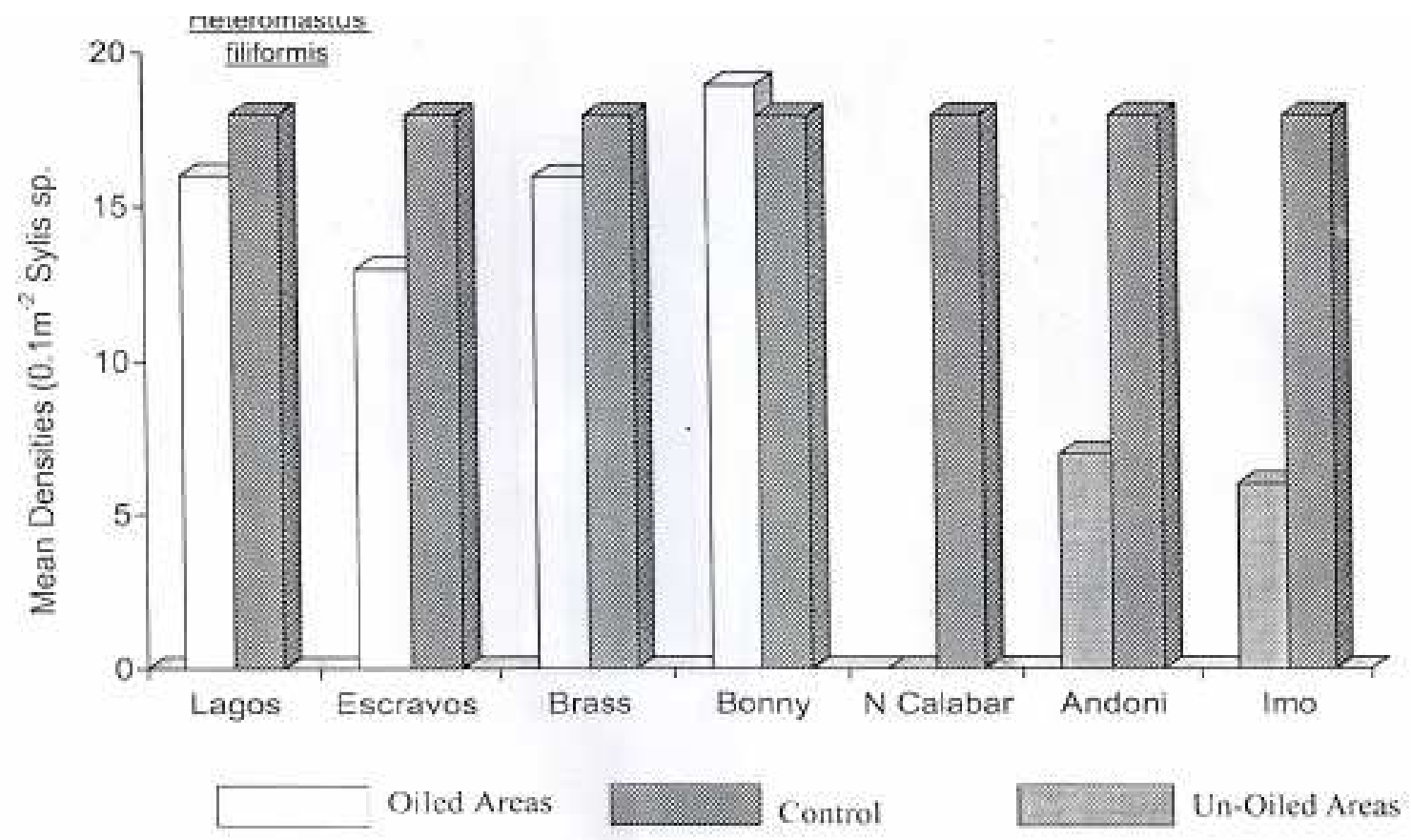

Fig. 3. Mean population density of Heteromastus filiformis in the oiled and non-oil areas (HTL/MTL 1998)

Fig. 4-7 plot mean population densities for opportunistic polychaetes sampled quantitatively from oiled areas of Lagos, Escravos, Brass and Bonny and non-oiled areas of Andoni, Imo and Cross River (control) at high and mid-tidal levels. The polychaetes family Capitellidae includes several opportunistic species, e.g. Capitella capitata and Heteromastus filiformis, capable of reaching high densities in the presence of abundant organic detrital food and absence of competitors. Fig. 4 shows the increase in population density of Heteromastus filiforms for the oiled compare with the non-oiled areas. As with Heteromastus there is a dramatic increase in abundance of Polydora (Fig. 5). The population density of $C$. capitata was not as dramatic as in other species (Fig. 6). Mean population of Nereis sp. was found to have reduced when compared 
with densities at the non-oil sites and the control, though densities reached were not as high as with other species (Fig. 7).

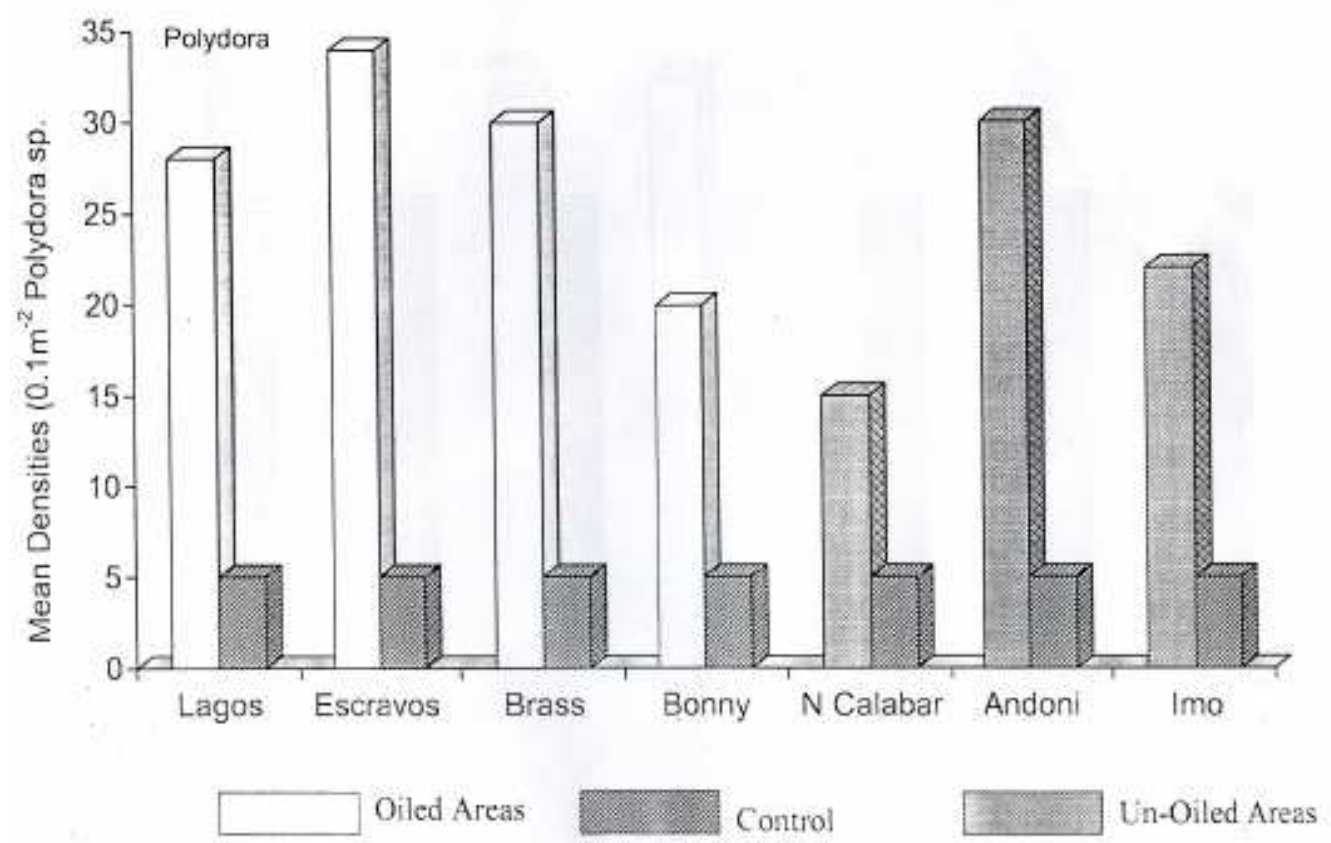

Fig.4. Mean population density of Polydora sp. in the oiled and non-oiled area (HTL/MEL 1998)

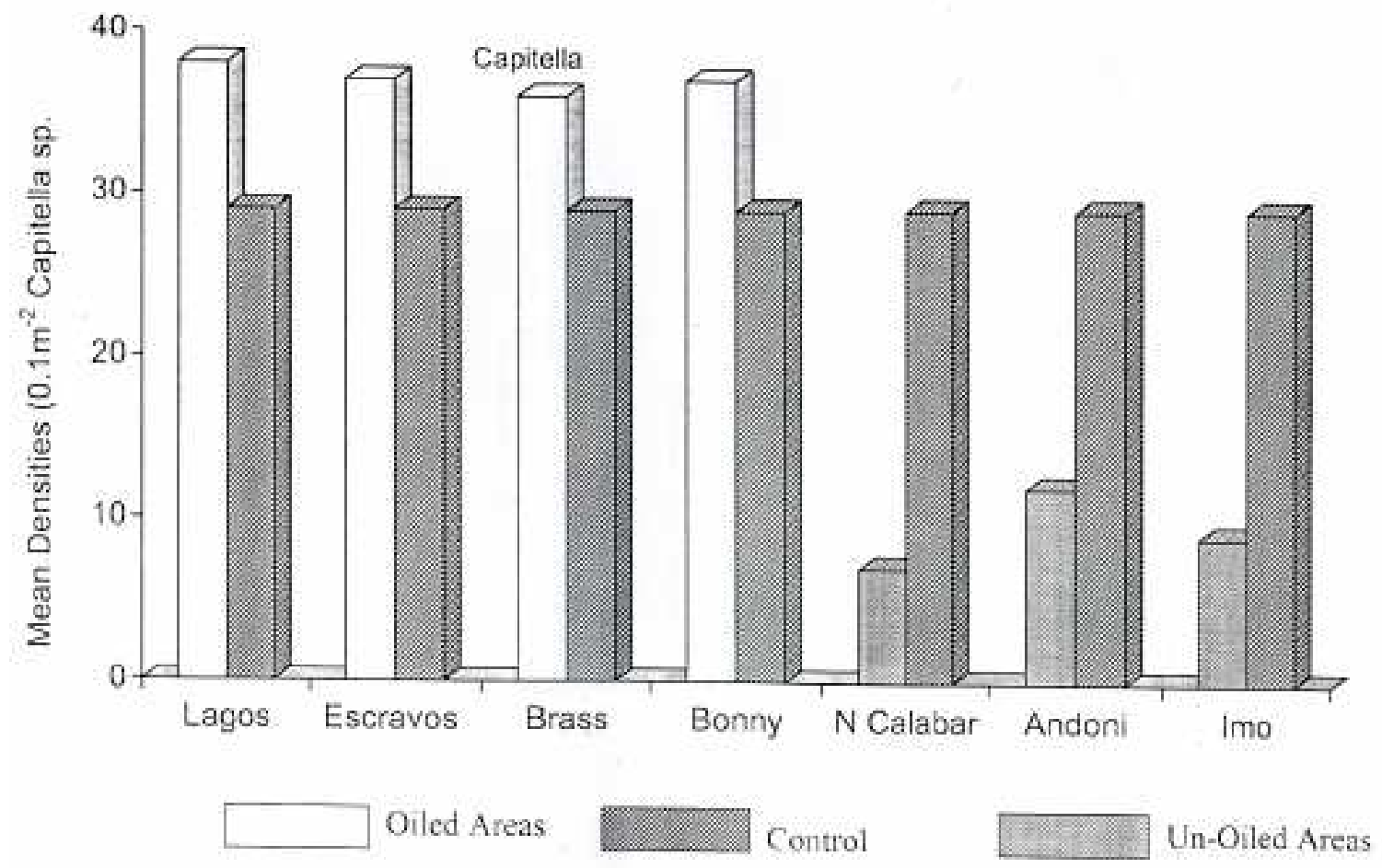

Fig. 5. Mean population density of Capitella sp. in the oiled and unoiled areas (HTL.MEL 1998) 


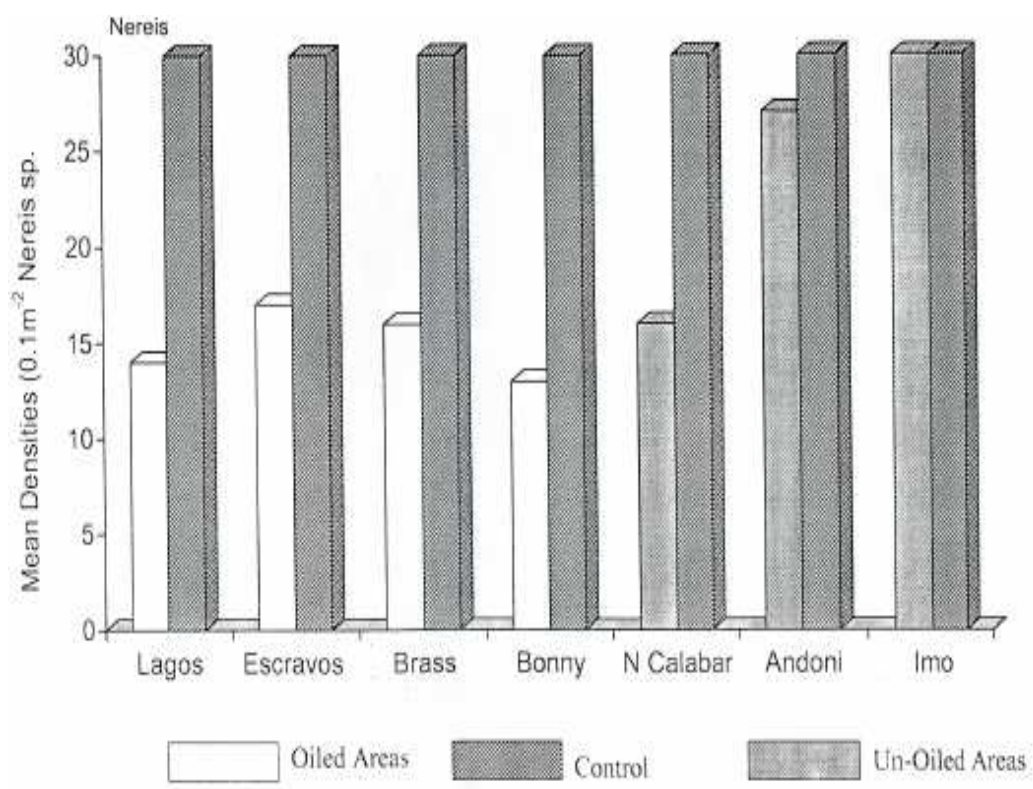

Fig. 6. Mean population density of Neries sp. in the polluted and unpolluted areas (HTUMTL 1998)

\section{Sediment}

\section{Discussion}

Particle grade analysis showed that sediment in the region was mostly silt-clay with small proportions of sand, conforming to that of most mangrove ecosystems previously studied (Macnea, 1968; Dangana, 1980; Ekweozor, 1985; Ombu, 1987; Ewa-Oboho, 1988, 1993, 1994). This stems from the fact that the sampling locations were mostly sheltered, which favoured the depositon of high volumes of silt carried in from run-offs and adjoining rivers. The organic matter content of silt-clay presumably plays some vital role in attracting deposit feeders to this habitat. Fine silt and clay generally represent a stable wave and current regime, but are structurally homogeneous.

A heterogeneous sediment of varying particle size gives more structural heterogeneity and potential niche spaces and, therefore, higher species diversity. The low zoo-benthic diversity observed in the area was perhaps because the bottom in most sites sampled was soft mud of silt/clay sediment. Under the circumstances, benthic infaunal species are faced with anoxic environmental conditions caused by abundance of microbes which constantly use up oxygen. Besides, the constant clogging of fine and delicate morphological structures, hindering respiration and feeding, even in the presence of abundance of organic matter, is also a critical factor limiting faunal densities in soft muddy bottoms prevalent in the survey.

The level of organic carbon of the sediment is a major factor that influences the distribution of benthic fauna, especially the deposit feeders (Beukema, 1976). Higher levels of organic matter favour higher densities and species diversities of macrozoo-benthos in marine sediments (Beukema, 1976). Increased organic carbon of sediment has been associated with major oil spills. Together with the high clay/silt sediment characteristics of the area, it was not surprising, therefore, that the major substrate types in Lagos, Escravos, Brass and Forcados had significantly higher percentage organic carbon in the sediment which harboured lower fauna densities in the oiled than in the unoiled areas (Table 1). This decreases in density could be ascribed to the long period of stay of petroleum hydrocarbons within the fine/clay sediment particles, thus, prolonging the toxic effects. 


\section{Faunal population densities}

Impacted benthic communities usually respond to oiling stress, the extent of which depends on the severity of the oiling. In most severe cases, infaunal communities suffer drastic reduction in densities (Ewa-Oboho, 1988, 1994; Levell, 1975). Only a few opportunistic species will be found in large numbers shortly after-spill. In simulated oil spill studies Uca juveniles were found massively exterminated by oiling of the Bonny mud flat (Ewa-Oboho, 1994). Usually, opportunistic species are stress-enduring with very large population size and relatively high reproduction rates. They invade stressed environment where they may grow to very large numbers. Following the Odoho oil spill, one can, therefore, determine the post-impact on infaunal communities by comparing (a) degree of invasion by opportunistic groups, (b) degree of opportunism of the species that invade the area, and (c) mean densities of indigenous species.

In the study, three opportunistic polychaetes were generally observed, namely Polydora sp., Heteromastus filiformis and Capitella capitata. Using the above criteria, it was possible to ascertain the effect of the spill on the benthos. Firstly, the area densities of Polydora spp., $H$. filiformis and Capitata species, at the oiled stations (estuaries) were more than densities at the unoiled estuaries, suggesting the apparent stability of opportunism demon-strated by the species. As tropical estuaries are constantly under stress from various toxicants and stress induced by constantly changing environmental factors, opportunism has become an important biological phenomenon in the estuaries whether oiled or not; thus, explaining the occurrence of Polydora sp., H. filiformis and C. capitata in the control (Cross river) and the unoiled estuaries of New Calabar, Andoni and Imo rivers (Fig. 4, 5 and 6). No compatible earlier records are available to compare with the densities and number of most species presently found, because of the variety in sample sizes and instrument employed in the relatively few earlier studies. However, the distinct differences in species density, as illustrated in Fig. 4, 5 and 6, leave little doubt that this is a persistent phenomenon.

Coarse sand and high current habitats close to the mouths of the estuaries of Bonny, Imo and Cross rivers may explain the low species densities in these areas. The physical stress exerted by water movement on the bottom may be an obvious factor involved. This could cause fragile species to be mechanically removed, preventing recruits from colonizing an area or food particles from reaching the bottom. With a sparse food supply, competition will be severe, which can lead to a reduction in the number of individuals and species. The mudflat crabs and periwinkles were found to have reduced in number after the 1998 spills, when densities were compared with earlier records and control clean sites (Ewa-Ohoho, 1998, 1994). It may well also be that reduction in densities of these species, particularly the periwinkles, could be due to human interaction, being a source of food for most communities in the area.

Although a comparison between previous and present data on faunal biomass is hampered by large variance and sampling grid, some general trend appeared to be consistent, namely that biomass of species generally decreased with severity of oiling (Ewa-Oboho, 1994). This was the case in the present studies as biomass of taxa decreased with oiling effect. The high biomass values of muluscs could be due to the large numbers of a few large individuals of Abra species collected during this period. As species diversity on impacted locations has not improved after 9 months of the spill compared with the control sites, recruitment for replacement of species must have been slow, showing that the environment in these areas had not recovered 9 months after the

spill. This generally agrees with the time-scale for full recovery of mangrove swamps from spilled oil effects, which is between 2-3 years (Ewa-oboho, 1998; in press).

\section{Conclusion}

Some of the inferences drawn from this study are biomass of macro-fauna decreased with severity of oiling. There was evidence of adverse effects of the oil spill on benthic infaunal organisms 9 
months after spills, as mean densities of organisms in control areas were different from those in the oiled and unoiled areas. There was clear evidence of some opportunistic species (e.g. Cepitella sp. and Polydora sp.) tending to increase in numbers but this cannot be clearly ascribed to the Idoho oil spill, as the area is consistently under stress of organic infusion from urban wastes as well as minor occasional oiling. The edible gastropod Tympanotomus fuscatus and the ocypodid crab Uca tangeri showed significant reduction in mean population densities in the oiled area when compared with densities in unpolluted sites. It is possible that these cannot be ascribed to the spill as these animals may have been fished for food by the inhabitants of these areas. Reduction in densities could, therefore, have been due also to direct human intervention in the area.

\section{Acknowledgement}

The authors thanks Mrs Eme Ita Ewa and Mrs Oladimeji for their great moral support during the project. Thanks are also due to Dr Abby-Katio and Prof. R. Kumar for useful discussions that improved the manuscript. Logistic support was provided by Exxon-Mobil, Nigeria.

\section{References}

Beukema J. J. and Essink K. (1986). Common patterns in the fluctuation of macrozoo benthic species lining at different places on tidal flats in the Wadden Sea. Hydrobiologia 199-207.

Beukema J. J. (1976). Biomass and species richness of the macro benthos living on tidal flats of the Dutch Wadden Sea. Neth J. Sea Res. 10(2): 236-261.

Boesch D. F. and Rosenburg R. (1981). Response to stress in marine benthic communities. In Stress effects on natural ecosystems. (G. W. Barett and R. Rosenburg, ed.), pp. 179-200. John Wiley \& Sons, New York.

Boesch F., Butler J. N., Cacchione D. A., Geraci J. R., Neff J. N., Ray J. P. and Teal J. M. (1986). An assessment of the long-term environmental effects of U. S. off-shore oil and gas development activities. Future research needs. In Effects of off-shore oil gas production. (D. F. Boesch, ed.), pp 1-55. Pergamon Press, New York.

Buchana J. B. and Kain R. C. (1977). The determination of organic matter in marine needs. J. exp. Mar. Bio. Ecol. 5: 158-69.

Clark R. B. (1982). The impact of oil pollutions, communities and ecosystems: a summing up. Phil. Trans. R. Soc. Lond. B 297: 433-443. Reprinted in R. B. Clark (ed.) 1982. The long term effect of oil pollution in marine population, communities and ecosystems. The Royal Society, London.

Dangana L. B. (1980). Hydrogeomorphological ecosystem in parts of Cross River State. In The mangrove Ecosystem of the Nigeria Delta. (B. H. R. Wilcox and C. B. Powell, ed.) University of Port Harcourt, Nigeria.

Ekweozor I. K. E. (1985). A baseline survey for the monitoring of oil pollution in the Bonny Estuary, Nigeria. (MPhil. Thesis.) River State University of Science and Technology, Port Harcourt, Nigeria. 217 pp.

Ewa-Odoho I. (1988). Effects of simulation of crude oil spill on the bonny mangrove swamp (MPhil. Thesis.) University of Science and Technology, Port Harcourt, Nigeria. $216 \mathrm{pp}$.

Ewa-Oboho I. (1993). Substratum preference two estuarine crabs Uca tangeri Eydoux (Ocypodidac) and Ocypode cursor linne (Ocypodidae) found in Nigeria mangrove ecosystem. Hydrobiologia 271: 119-127.

Ewa-Oboho I. (1994). Effects of simulated oil exposure on two intertidal macro-zoo benthos Tympanotomus fuscata (L) and Uca tangeri (Eydoux 1935) in a tropical mangrove ecosystem. Exotox. envir. Saf. 28: 243.

Ewa-Oboho I. (1988). Effect of Mobil-Idoho Oil Spill on estuaries benthos in January 1998. Idoho-QIT 24 Pipeline Oil Spill. Post impact assessment. Final Report for Mobil Producing, Nigeria.

Holme N. A. (1969). Methods of sampling the Benthos. Adv. Mar. Biol. 2: 171-269.

Jones A. D. (1986). A field guide to the sea shore of Kuwait and Arabia Gulf. Blandford Press. U. K.

Jone D. A., Plaza J., Watt I. and Sane. M. (1996). Long term (1991-1995) monitoring of the intertidal biota of Saudi Arabia after the 1991 Gulf War Oil Spill. Mar. Pollut. Bull. 36: 472-489.

Jones D. A. and Richmond M. D. (1993). Intertidal and subtidal marine habitat surveys. Establishment of marine habitat and wild life sanctuary for the Gulf Region. Final report for Phase 1. CEC/NCWCD. Jubai/Frankfurt. Germany.

Jones D. A. Watt I, Plaza J. and Woodhouse T. D. (1996). Natural recovery of the intertidal biota within the proposed marine habitat and wild life sanctuary for the Arabia Gulf War Oil spill. (F. Krupp, A. H. Abuzinada and I. A. Nda, ed.), pp. 138-158. NCWCD Riyadland Senckenberg Institute, Frankfurt. Germany.

Koons C. B. and Gould H. R. (1988). Worldwide status of research on fate and effects of oil in the marine environment 1982. Special Report, Exxon Production Research. 
Levell D. (1975). Effect of Kuwait crude worm, Arenicola Marina (L). In Marine ecology and oil pollution. (J. M. Baker, ed.), pp. 131-158.

Lewis J. L. (1982). The composition and functioning of benthic ecosystem in relation to the assessment of long-term effect of oil pollution. Phil. Trans. R. Soc. Lond. B. 297: 267.

Macnea W. (1968). A genera account of the fauna and flora of mangrove swamps in Indo-West Pacific Region. Adv. Mar. Biol. 673: 270 .

Mc Glade J. M. and Prince A. G. (1993). Multi-disciplinary modeling: an overview governance of the Gulf Region. Mar. Pollut. Bull. 27: 361-376.

Mc Intyre, A. D. and Pearce J. B. (ed.) (1980). Biological effects of marine pollution and the problem of monitoring. Rapp. P.-V. Reun. Cons. Int. Explor. Mer. 179: 1-346.

Mc Man U. G and Buller (1975). Some responsible of tropical mangrove fiddle Uca crabs sp. to high environment temperature. In 12th European Mar. Biol. Symp. (D. S. Mc Lusky and A. J. Berry, ed.), 49-56. Pergamos Press, Oxford.

Morgans J. F. C. (1956). Notes on the analysis of shallow water soft strata. J. Ecol. 3: 337-387.

Ombu I. E. (1987). The impact of Okiriko Oil Terminal on littoral benthos of the Bonny Estuary. (MPhil. Thesis.) University of Science and Technology, Port Harcourt, Nigeria.

Ovaitt C. A. Frithsen J. Gearing J. and Gearing P. (1992). Low chronic additions of No. 2 fuel oil: Chemical behaviour, biological impact and recovery in a simulated estuaries environment. Mar. Ecol. Prog. Ser. 9: 121-136.

Oviatt C. A., Pilson M. E. O., Nixon S. W., Frithsen J. B., Rudnick J. R. Kelly J. R., Grassie J. F. and Grassie, J. P. (1994). Recovery of a polluted estuaries system. A mesocosm experiment. Mar. Ecol. Prog. Ser. 16: 203-217.

Prena J. (1996). The status of intertidal soft bottom macrofauna six months after the Gulf War oil Spill. Marine Wildlife. Sell et. al. (1995). 